\title{
PENGGUNAAN BAHASA INDONESIA DALAM SURAT DINAS DI INSTANSI PEMERINTAH DESA SEMAMBUNG KECAMATAN GEDANGAN KABUPATEN SIDOARJO PERIODE SEPTEMBER- OKTOBER 2018
}

\author{
Windy Kusumaning Tyas \\ (Pendidikan Bahasa Indonesia, Fakultas Keguruan dan Ilmu Pendidikan, Universitas \\ PGRI Adi Buana Surabaya) \\ windyprawira@gmail.com \\ Taufik Nurhadi \\ (Pendidikan Bahasa Indonesia, Fakultas Keguruan dan Ilmu Pendidikan, Universitas \\ PGRI Adi Buana Surabaya) \\ taufiknurhadi70@gmail.com
}

\begin{abstract}
This study aims to describe the form of misuse of words in making official letters. The research data is based on the type of official letter that entered the Semambung Village Government in 2018. Data analysis was divided into two types, namely primary and secondary data. Primary data in this study is written data about language errors, namely errors in the form of word accuracy, word correctness, writing errors, generality, and word efficiency.The method used in this study, namely a qualitative approach. Data from this study are in the form of words. The source of the data in this study is official letters that are included in the government agency of Semambung Village, Gedangan District, Sidoarjo Regency in 2018. Data collection techniques in this study use note-taking techniques. Based on the results of data analysis there are errors in the use of Indonesian in official letters entered by the Semambung Village Government in Gedangan District, Sidoarjo Regency in 2018. In this study it can be concluded that language errors in the form of deviations in the form of errors in word accuracy, word rigidity, economics, subtlety and meaning.
\end{abstract}

Keywords: Service, letter

\section{PENDAHULUAN}

Peranan sebuah surat di dalam sebuah instansi pemerintahan akan memiliki fungsi yang sangat penting. Salah satu fungsinya adalah cara berkomunikasi baik lisan maupun secara tertulis untuk mencapai pelayanan yang diinginkan. Kegiatan surat menyurat itu sendiri masih sering ditemui di dalam instansi pemerintah, perusahaan dan berbagai kegiatan dimasyarakat.

Oleh karena hal itu, peneliti merasa tertarik untuk dijadikan objek penelitian lebih lanjut. Surat selain sebagai sarana alat komunikasi juga sebagai wakil dari pembuatan surat, bahan bukti secara tertulis, sumber data, bahan pengingat, bahan pengikat, bahan promosi dan alat penghemat baik waktu, tenaga dan biaya. Berhubungan dengan permasalahan diatas, teknik penulisannya dapat dilakukan dengan cara menyediakan surat dinas. Berdasarkan hasil observasi awal di dalam surat masuk di pemerintahan desa sering ditemukan kesalahankesalahan yang telah membudaya sehingga sudah menjadi sebuah 
kewajaran yang sebaiknya harus segera disempurnakan agar lebih baik.

Dari uraian diatas maka akan ditarik rumusan masalah yaitu bagaimana bentuk kesalahan berbahasa yang digunakan surat dinas di pemerintah Desa Semambung Kecamatan Gedangan Kabupaten Sidoarjo Periode September - Oktober 2018 ?

\section{METODE PENELITIAN}

Sumber data dalam penelitian surat dinas yang masuk di pemerintah

\begin{tabular}{|c|c|c|c|c|c|c|c|}
\hline \multirow[t]{2}{*}{ No } & \multirow[t]{2}{*}{ Bagian Surat } & \multicolumn{6}{|c|}{$\begin{array}{c}\text { Bentuk } \\
\text { Penyimpangan }\end{array}$} \\
\hline & & 1 & 2 & 3 & 4 & 5 & 6 \\
\hline 1. & Kepala & & & & & & \\
\hline 2. & Nomor & & & & & & \\
\hline 3. & Tanggal & & & & & & \\
\hline 4. & Perihal & & & & & & \\
\hline 5. & Alamat tujuan & & & & & & \\
\hline 6. & $\begin{array}{l}\text { Salam } \\
\text { pembuka }\end{array}$ & & $\sqrt{ }$ & & $\sqrt{1}$ & & \\
\hline 7. & Isi & $\sqrt{ }$ & $\sqrt{ }$ & & $\sqrt{ }$ & $\sqrt{ }$ & $\sqrt{ }$ \\
\hline 8. & Salam penutup & & $\sqrt{ }$ & $\sqrt{1}$ & $\sqrt{1}$ & $\sqrt{ }$ & \\
\hline 9. & Pengirim surat & & & & & & \\
\hline 10. & Lampiran & & & & & & \\
\hline 11. & Tembusan & & & & & & \\
\hline
\end{tabular}

Desa Semambung Kecamtaan Gedangan Kabupaten Sidoarjo periode September-Oktober 2018.

Data kajian ini adalah pilihan kata yang berada di dalam surat dinas meliputi ketepatan, kebakuan, keumuman, kehematan dan kehalusan makna. Prosedur penganalisisan data melalui pendekatan deskriptif kualitatif dengan cara mencermati kembali data dalam bentuk transkrip kata yang mengandung kesalahan berbahasa dan menyimpulkannya dengan mendeskripsikan ke dalam kesalahan berbahasa.

Teknik pengumpulan data dalam penelitian ini dilakukan dengan metode tulis dan catat. Teknik menulis dengan cara menulis bentukbentuk kesalahan bahasa di dalam surat dinas dengan menggunakan mata sebagai alat penglihat. Sedangkan teknik catat digunakan secara langsung ketika menganalisis surat dengan menggunakan alat catat berupa pencatatan.

Analisis data dalam penelitian ini dengan menggunakan pendekatan deskriptif kualitatif. Dengan menggunakan deskritif kualitatif berfungsi mendeskripsikan atau memberi gambaran terhadap objek yang diteliti melalui data atau sampel yang telah terkumpul sebagaimana adanya tanpa melakukan analisis dan membuat kesimpulan yang berlaku umum.

\section{HASIL DAN PEMBAHASAN}

Pengumpulan hasil data penelitian tentang "Penggunaan Bahasa Indonesia Dalam Surat Dinas Di Instansi Pemerintah Desa Semambung Kecamatan Gedangan Kabupaten Sidoarjo Periode September - Oktober 2018" disajikan sebagai berikut.

Keterangan $=(1)$ ketepatan kata, (2) kebakuan kata, (3) keumuman, (4) kehematan, (5) kehalusan, (6) makna;

\section{Data Bahasa}

\section{a) Ketepatan Kata}

Ketepatan kata adalah pemilihan kata yang sesuai dengan ide yang akan disampaikan, sesuai dengan situasi, dan sesuai dengan posisi pembicara (Dirgo Sabarianto:8).

"Dengan ini kami beritahukan bahwa pelaksanaan Imunisasi ORI (Outbreak Respon Imunisation) putaran ke III pada anak usia 1 s/d 5 tahun, dimana akan diberikan di Posyandu pada :" 
Berdasarkan kutipan di atas, ketepatan kata terdapat kata "putaran", penggunaan bentuk "putaran" dinilai kurang tepat, karena putaran lebih berarti gerakan berputar atau mengarah pada beberapa kali gerakan berputar. Penggunaan bentuk "putaran" dapat mengarah ke bentuk konotatif yaitu lebih mengarah ke benda yang berputar. Sedangkan dalam konteks ini yang dibicarakan adalah pelaksanaan Imunisasi ORI urutan ke III, sehingga diperlukan penggantian kata "putaran" dengan bentuk persamaannya atau sinonimnya. Persamaan atau sinonim yang tepat dalam konteks ini adalah kata tahap. Tahap lebih mengarah kepada urutan, dengan menggunakan kata tahap berarti ada tingkatan pertingkatan yang bisa dilakukan atau dilalui. Dengan penggunaan kata tahap akan lebih memperjelas bahwa tujuan surat ini mengarah kepada pemberitahuan pelaksanaan Imunisai ORI pada tingkatan atau tahap ke III. Sehingga seharusnya menjadi "Dengan ini kami beritahukan bahwa pelaksanaan Imunisasi ORI (Outbreak Respon Imunisation) tahap ke III pada anak usia 1 s/d 5 tahun, dimana akan diberikan di Posyandu pada :".

\section{b). Kebakuan Kata}

Kata-kata yang dipergunakan untuk membuat struktur kalimat harus yang baku (Dirgo Subarianto:10). Kabakuan kata sangat diperlukan dalam penulisan surat, mengingat kata baku menjadi syarat penulisan surat resmi. Bahkan penggunaan kata baku juga harus sesuai dengan kaidah bahasa Indonesia yang baik dan benar. Seringkali dalam surat kata tidak baku ini berhubungan dengan pembentukan katanya, misalkan kesalaan penulisan kata yang semestinya digabung ternyata tidak digabung, serta ejaan yang salah.

\section{c). Kesalahan Penulisan}

* "Perihal sebagai mana pada pokok surat"

Pada kutipan di atas bentuk kata yang tidak baku yang terdapat dalam surat ini yaitu terdapat pada bagian isi surat terdapat kata "sebagai mana". Bentuk "sebagai mana" merupakan dari kata dasar "bagaimana" yang megalami proses afiksasi atau imbuhan diawal yaitu "se+bagaimana". Kata dasar "bagaimana" tidak dapat dipisah meskipun mendapat imbuhan. Menurut ejaan bahasa Indonesia dan kamus besar bahasa Indonesia "sebagaimana" memiliki arti seperti halnya,sebagai halnya, atau sama halnya dengan, sedangkan "sebagai mana" tidak memiliki arti yang jelas dan bukan merupakan bentuk baku. Sehingga seharusnya adalah "perihal sebagaimana pada pokok surat".

* "Menindak lanjuti surat Dinas Sosial Kabupaten Sidoarjo"

d). Kesalahan Proses Pengimbuhan (Afiksasi)

\begin{tabular}{llr}
\multicolumn{2}{c}{ Kesalahan proses afiksasi } \\
merupakan kesalahan & pada \\
pembentukan & kata atau proses
\end{tabular} morfofonemik. Bentuk afiksasi prefiks (awalan) meN + , apabila digabungkan dengan bentuk kata dengan fonem awal $\mathrm{k}, \mathrm{p}, \mathrm{t}, \mathrm{s}$ akan mengalami peluruhan. Jika meN+ fonem awal " $k$ " dalam kata kupas, bukan mengkupas tetapi fonem " $\mathrm{k}$ " mengalami peluruhan sehingga menjadi "mengupas". Begitu juga dengan bentuk fonem awal "s" pada kata sapu, yang bukan mensapu tetapi menyapu. Tetapi perlu diketahui bentuk meN+k/p/t/s tidak akan luruh apabila berbentuk kluster dan digraf seperti contoh berikut meN+pr dalam 
kata protes, bukan memrotes tetapi memprotes. Berikut ditemukan bentuk kesalahan pembentukan kata karena kesalahan proses pengimbuhan atau afiksasi.

* "Masyarakat guna mensukseskannya pada :'Pada kutipan di atas kata "mensukseskannya" yang merupakan dari proses meN+sukses+kan+nya. Bentuk sukses berawal dengan fonem "s" yang seharusnya dalam proses afiksasi akan mengalami peluruhan karena "sukses" bukan merupakan bentuk kluster atau digraf. Sehingga semsetinya "s" itu luruh menjadi bentuk "menyukseskan" dari proses afiksasi meny+sukses+kan+nya. Sehingga menjadi "Masyarakat guna menyukseskannya pada Kesalahan dalam penggunaan huruf kapital atau huruf besar seringkali ditemukan dalam surat khususnya surat dinas. Kesalahan penggunaan huruf kapital akan mengakibatkan surat tersebut dibuat tidak berdasarkan kaidah ejaan bahasa Indonesia yang baik dan benar.

\section{e). Kesalahan Penggunaan Huruf Kapital}

Penggunaan huruf kapital digunakan untuk penulisan nama geografi atau tempat, untuk menulis nama tahun, bulan, hari, tanggal, hari raya dan peristiwa sejarah, penulisan unsur pertama kata awal kalimat, penulisan nama orang, penulisan awal setiap kata dalam judul, huruf kapital juga digunakan dalam penulisan huruf pertama kata penunjuk kekerabatan. Namun dalam kenyataanya masih ditemukan kesalahan penulisan huruf kapital dalam surat khususnya surat dinas. Hal tersebut terbukti ditemukan dalam data penelitian yang diuraikan berikut ini.

* " untuk mengundang bapak/ibu agar turut serta hadir"
Bentuk "bapak/ibu" merupakan bentuk penunjuk kekerabatan antara seseorang penulis dengan orang yang dituju, penulis menyatakan kekerabatan dengan menggunakan bentuk bapak/ibu dikarenakan penulis surat sadar betul bahwa hubungannya dengan seseorang tujuan surat itu adalah dekat atau menunjukkan kesantunannya mengingat yang diundang adalah seorang Kepala Desa setempat. Karena hubungan antara Kepala Desa dengan masyarakatnya adalah dekat dan harus terjalin keakraban. Namun penulisan bapak/ibu dalam surat ini seharusnya menggunakan huruf awal kapital menjadi Bapak/Ibu, sehingga seharusnya " untuk mengundang Bapak/Ibu agar turut serta hadir"

* Demikan untuk menjadikan maklum

Pada kutipan di atas penggunaan kata "maklum" diatas merupakan bentuk yang kurang umum. Hal ini dikarenakan bentuk kata tersebut tidak bersifat umum yang biasanya diketahui masyarakat. Kata tersebut yang lebih tepat sesuai dengan kaidah penggunaan bahasa surat dinas yang baik dan benar yaitu " Demikian atas perhatiannya kami ucapkan terima kasih".

\section{f). Keumuman}

* Demikan untuk menjadikan maklum

Pada kutipan di atas penggunaan kata "maklum" diatas merupakan bentuk yang kurang umum. Hal ini dikarenakan bentuk kata tersebut tidak bersifat umum yang biasanya diketahui masyarakat. Kata tersebut yang lebih tepat sesuai dengan kaidah penggunaan bahasa surat dinas yang baik dan benar yaitu "Demikian atas perhatiannya kami ucapkan terima kasih". 


\section{g). Kehematan Kata}

Unsur pembangun sebuah kalimat adalah kata. Sehingga memenuhi unsur kehematan kata atau tidak boleh mengandung unsure mubazir. Namun dalam kenyataannya mamsih banyak ditemukan bentuk ketidakhematan kata dalam surat, khususnya dalam surat dinas. Berikut bentuk ketidakhematan kata dalam surat dinas.

* “ Sehubungan dengan agenda peresmian Ruang Guru bantuan dari CSR PT. Angkasa Pura I Surabaya, maka dengan ini kami bermaksud untuk mengundang Bapak/ Ibu agar turut serta hadir pada acara tersebut yang akan dilangsungkan pada:"

Ketidakhematan pada surat tersebut terletak pada kata "turut" dan "serta" yang hanya menjadi penghubungan antar kata, apabila kata "turut" dan "serta" dihilangkan maka tidak akan memperngaruhi makan dari kalimat surat tersebut, sehingga menjadi "Sehubungan dengan agenda peresmian Ruang Guru bantuan dari CSR PT. Angkasa Pura I Surabaya, maka dengan ini kami bermaksud untuk mengundang Bapak/ Ibu agar hadir pada acara tersebut yang akan dilangsungkan pada:". Setelah kata "agar" dilanjutkan dengan kata "hadir" akan dirasa lebih mempersingkat dan memperjelas makna dan pembaca akan merasakan perbedaan membaca dengan ada tidaknya bentuk "turut"dan "serta" yang dirasa tanpa bentuk tersebut membacanya akan merasa tidak bertele-tele atau bisa juga menggunakan salah satu bentuknya saja yaitu "turut" saja agar tidak terjadi pemborosan kata.

Kesalahan yang juga sering ditemukan yaitu kesalahan yang berhubungan dengan pembentukan kata dan penulisan. Kesalahankesalahan tersebut sangat ditentukan oleh faktor kemampuan berbahasa yang baik penulis surat. Seperti contoh dibawah ini.

* "Mendasari surat Kepala Dinas Kepemudaan, Olah Raga dan Pariwisata Kabupaten Sidoarjo"

Bentuk "Olah raga" bukan merupakan bentuk yang baku, hal ini dikarenakan bentuk "Olah Raga" berarti mengolah raga sedangkan Kamus Besar Bahasa Indonesia penulisannya adalah "olahraga" yang merupakan gerak badan untuk menguatkan dan menyehatkan tubuh bukan "olah raga". Bentuk "olah raga" bisa berarti mengolah badan atau raga tetapi salah dalam penulisannya karena merupakan kesatuan yang penulisannya harus digabung menjadi "olahraga". Penulisan yang salah akan menjadikan kata tersebut tidak baku karena tidak sesuai dengan kaidah penulisan bahasa Indonesia yang baik dan benar. Sehingga dalam surat tersebut seharusnya adalah "Mendasari surat Kepala Dinas Kepemudaan, Olah Raga dan Pariwisata Kabupaten Sidoarjo".

Berdasarkan uraian tersebut maka dapat diketahui faktor kemampuan penulis surat, apabila yang terjadi diatas dapat diketahui yaitu bisa jadi bukan faktor kemampuan saja tetapi faktor usia penulis. Bentuk "olahraga" bagi kaum muda atau usia muda pasti tidak asing dan sering menjumpai bentuk ini dimanapun, sehingga mereka tidak salah dalam penulisannya. Akan tetapi lain halnya dengan kasus seperti diatas. Mungkin penulis adalah orang yang berusia lanjut atau tua yang jarang menemukan bentuk "olahraga" sehingga ia menulis bentuk yang salah. 
Kesalahan yang sering dan umum dilakukan yaitu kesalahan penggunaan huruf kapital, pembentukan kata, serta penulisan kata. Hal ini sudah selayaknya untuk diperhatikan penulis surat.

Penulisan huruf kapital, meliputi kesalahan penulisan nama bahasa. Huruf kapital sebagai huruf pertama nama bangsa, suku, dan bahasa. Penulisan huruf kapital hanya nama bangsa, nama suku, dan nama bahasa: kata bangsa, suku, dan bahasa ditulis dengan huruf kecil jika berada di tengah kalimat. Kesalahan penulisan nama orang. Huruf kapital digunakan sebagai huruf pertama unsur-unsur nama orang. Kesalahan penulisan nama bulan. Huruf kapital digunakan sebagai huruf pertama nama tahun, bulan, hari, hari raya, dan peristiwa sejarah. Huruf kapital digunakan sebagai huruf pertama semua kata di dalam nama orang, awal kalimat, nama lembaga dan lain sebagainya, kecuali kata seperti, $d i$, $k e$, dari, dan, yang, dan untuk yang tidak terletak pada posisi awal.

Penulisan huruf miring, meliputi kesalahan penulisan judul novel, buku, majalah, dll. Huruf miring digunakan untuk menuliskan nama buku, majalah, dan surat kabar yang dikutip dalam karangan. Kesalahan penulisan kata yang akan dijelaskan/dipaparkan,

misalnya"Dengan ini kami beritahukan bahwa pelaksanaan Imunisasi ORI (Outbreak Respon Imunisation) putaran ke III pada anak usia 1 s/d 5 tahun, dimana akan diberikan di Posyandu pada". Huruf miring digunakan untuk menegaskan atau mengkhususkan huruf, bagian kata, atau kelompok kata.

Kesalahan penulisan kata, meliputi kesalahan penulisan "di" dan "ke" sebagai kata depan/preposisi.
Jika "di" dan "ke" merupakan kata depan/preposisi maka penulisannya dipisah. Jika "di" dan "ke" merupakan awalan maka penulisannya digabung/dirangkai. Kesalahan penulisan kata tidak baku, contoh kata tidak baku yaitu "subyek". Fonem 'y' seharusnya diganti menjadi fonem ' $j$ ' agar menajdi bentuk kata baku. Kesalahan penulisan kata turunan, yaitu apabila gabungan kata mendapat awalan dan akhiran sekaligus, maka penulisannya dirangkai/digabung.

Kesalahan penulisan tanda baca. Kesalahan penulisan tanda koma, yaitu pada suatu perincian. Kelompok kata tersebut merupakan suatu perincian, yang di dalam ejaan yang disempurnakan seharusnya sebelum kata "dan" diberi tanda koma. Kesalahan penulisan tanda titik. Tanda titik seringkali tidak digunakan pada akhir kalimat.

Banyak faktor yang melatarbelakangi terjadinya kesalahan tersebut, misalnya faktor yang utama yaitu kurang mengertinya penulis akan kaidah penggunaan bahasa Indonesia yang baik dan benar khususnya dalam penulisan surat dinas. Sehingga penulis surat dinas seharusnya terus berlatih dan belajar setiap saat tetang bagaimana penulisan surat dinas yang sesuai dengan kaidah bahasa Indonesia yang baik dan benar. Hal ini dirasa sangat penting mengingat seseorang biasanya akan mengesampingkan kaidah-kaidah penulisan yang benar dan secara tidak langsung akan menjadi bentuk-bentuk penggunaan atau penulisan bahasa dalam surat yang akan dicontoh oleh masyarakat. Apabila yang dicontoh masyarakat adalah penggunaan bahasa yang salah, maka akan berakibat penurunan penggunaan atau penulisan bahasa 
yang tidak sesuai dengan kaidah kebahasaan yang baik dan benar.

Kesalahan-kesalahan yang banyak ditemukan adalah berhubungan dengan kesalahan leksikal dan semantik. Kesalahan leksikal adalah kesalahan berbahasa yang berkaitan dengan kosakata, sedangkan kesalahan secara semantis adalah kesalahan berbahasa yang berhubungan dengan makna.

\section{SIMPULAN DAN SARAN}

Bentuk kesalahan berbahasa Indonesia yang ditemukan pada surat dinas di Instansi Pemerintah Desa Semambung terdapat 30 bentuk kesalahan. Kesalahan tersebut meliputi bentuk kesalahan ketepatan kata, kehematan kata, kebakuan kata, pembentukan kata, dan penggunaan huruf capital. Kesalahan tersebut bisa disebabkan banyak faktornya, misalkan kesalahan diakibatkan ketidaktahuan penulis surat, atau bisa jadi dikarenakan penulis surat ingin menjadikan tulisan dalam surat menjadi lebih indah atau baik namun ternyata malah menjadikan surat tersebut kurang baik dalam hal pemilihan katanya, misalkan tidak hemat kata.

Bentuk kesalahan berbahasa Indonesia yang paling dominan pada surat dinas di Pemerintah Desa Semambung adalah kesalahan dalam bagian isi surat. Adapun persebaran kesalahan berbahasa yang ditemukan pada surat dinas di Pemerintah Desa Semambung adalah: kesalahan dalam ketepatan kata, kebakuan kata, kehematan, kehalusan dan makna.

Penggunaan Bahasa Indonesia Dalam Surat Dinas di Instansi Pemerintah Desa Semambung Kecamatan Gedangan Kabupaten Sidoarjo Periode September Oktober 2018", adapun saran yang ingin disampaikan dalam penelitian ini sebagai berikut.

1. Bagi Pembaca

Dengan adanya penelitian ini, diharapkan dapat menambah wawasan dan pengetahuan pembaca mengenai ejaan yang disempurnakan.

2. Bagi Mahasiswa

Dengan adanya penelitian ini, diharapkan mahasiswa tidak melakukan kesalahan ejaan yang disempurnakan di dalam penulisan skripsi dan karya tulis yang lainnya.

3. Instansi Terkait

Dengan adanya penelitian ini, diharapkan mampu membuat surat dinas sesuai dengan kaidah penulisan yang baku dan sesuai Pedoman Ejaan Yang Disempurnakan.

\section{DAFTAR PUSTAKA}

Arifin, Zaenal dan Amran Tasai. 2008. Cermat Berbahasa Indonesia. Jakarta: Akademika Pressindo.

Departemen Pendidikan Nasional. 2008. Kamus Besar Bahasa Indonesia. Jakarta: PT Gramedia Pustaka Utama.

Ghufron, Syamsul. 2015. Kesalahan Berbahasa : Teori dan Aplikasi. Yogyakarta : Penerbit Ombak.

Kementerian Pendidikan dan Kebudayaan.2016. Buku Guru Bahasa Indonesia. Jakarta : Kementerian Pendidikan dan Kebudayaan.

Keraf, Gorys. 2010. Diksi dan Gaya Bahasa.Jakarta:PT. Gramedia Pustaka Utama

Kosasih. E., Sutari Ice. 2003. Surat Menyurat Menulis Surat Dinas Dengan Benar. Bandung:CV.Yarama Widya. 
Martono, E. 1993. Mahir Surat Menyurat Dinas Bahasa Indonesia. Jakarta:Karya Utama.

Tarigan, Henry Guntur. 2008. Menulis sebagai Suatu KeterampilanBerbahasa. Bandung:Angkasa.

Subarianto, Dirgo. 1988. Bahasa Surat Dinas: Yogyakarta:Mitra Gama Widya.

Sunroso, Eko dan Eko Sri Israhayu. 2014. Bentuk Kesalahan Bahasa Surat-Surat Dinas Yang Masuk Pada Prodi PBSI FKIP
Universitas Muhammadiyah Purwokerto 2014. Purwokerto.

Suyanto, Edi.2011.Membina, Memelihara, dan MenggunakanBahasa Indonesia SecaraBaik dan Benar.Yogyakarta:Ardana Media.

Universitas PGRI Adi Buana Surabaya. Skripsi. Prodi PBSI 2016 dan 2017.Surabaya.Universitas PGRI AdiBuana Surabaya. 